\title{
News media's position-taking regarding the European Union: The synchronization of mass media's reporting and commentating in the 2014 European Parliament elections
}

Silke Adam, Beatrice Eugster, Eva Antl-Wittenberg, Rachid Azrout, Judith Möller, Claes de Vreese, Michaela Maier, and Sylvia Kritzinger

\begin{abstract}
We analyse whether a newspaper's editorial position regarding the European Union is related to its selection decisions in the news section. We ask whether such a synchronization between news and editorials exists, whether it is conditioned by the type of media system and under which conditions it also affects the selection of transnational voices. Our study is based on a quantitative content analysis of the quality press in seven European countries (Austria, France, Germany, Greece, The Netherlands, Portugal and the United Kingdom) in the run-up to the 2014 European Parliament elections. Our results support a synchronization between editorials and news, specifically with regard to the selection of national speakers. With regard totransnational speakers, they are selectively chosen by a medium if its editorial position is not supported at the national level. Furthermore, they are used to put forward a portrayal of a political community in accordance with the editorial line.
\end{abstract}

KEYWORDS commentaries; editorial line; EU positions; mass media; news; synchronization

\section{Introduction}

The European Union (EU) is currently facing intense debates about its future. Crisis such as the economic and financial crisis as well as the migration crisis have stirred up debates about the future of the European integration process. Simultaneously, we observe an increasing proportion of European citizens negatively assessing the process of European integration, its institutions and its policies. This becomes most visible in the recent British decision to leave the EU, but also in the last European Parliament (EP) election. 
Euroscepticism is thus compared to a virus that 'has now spread across the continent' (Torreblanca et al. 2013: 1). This spread is remarkable given the fact that for long a permissive consensus has characterized the citizens' relationship with the EU. The question is how the virus of Euroscepticism could have been fuelled to such a large extent?

While recent research has examined extensively not only parties’ behaviours and citizens’ attitudes on the EU but also how mass media attach salience to Europe and how they reflect party positions on Europe, little research has been conducted on news media's independent position-taking on the EU. This research deficit is even more surprising as news media are important owing to their excellent 'access' to the citizens.

News media can play an independent role in formulating positions towards the EU, turning into political actors themselves (Page 1996). They do so legitimately in the editorial sections. In the reporting sections, in contrast, newspapers are expected to turn into conveyors of information independently of their editorial lines. Yet, research has shown that position-taking in editorials might also impact news selection by, for example, privileging those voices that support the editorial lines (e.g., Hagen 1993; Kahn and Kenney 2002). Consequently, we ask: Is a newspaper's editorial position regarding the EU related to its selection decisions in the news?

So far this ‘synchronization’ (Schönbach 1977) of editorials and news has primarily been studied in the realm of national politics. Here it is left-leaning newspapers that primarily refer to left-leaning sources, whereas the contrary applies to right-leaning newspapers (e.g., Hagen 1993). With the European integration process, however, issues are no longer decided at the national level, which also makes national mass media grant a voice (to different degrees and under specific circumstances [e.g., Adam 2016] to speakers of other member states or the EU. We thus ask: Is the editorial position of a newspaper regarding the EU related only to the selection of national voices or does it also impact the selection of transnational ones in the news section? We explore these questions by using a unique dataset on news media reporting 
and commentating about EU matters in the run-up to the 2014 EP elections which builds on the content of the right- and left-leaning quality press in seven EU member states 12 weeks preceding these elections.

Our contribution to research is threefold. First, we focus on media’s position-taking regarding the EU (for this research deficit, see Bijsmans [2015] and Vasilopoulou [2013]) and thereby offer a detailed picture of how 14 media outlets in seven European countries position themselves towards the EU. Second, we contribute to research on synchronization between editorials and news by distinguishing different approaches on how it can be measured, by empirically adding information on position-taking of political actors, and by showing how such studies can extend beyond the nation state. Third, by doing so, we also add to research on the Europeanization of national public spheres, as we study the role of editorial policies on the development of Europeanization processes.

\section{Media's position-taking regarding the European Union in commentaries and news}

In general, we can distinguish two ways in which news media can make clear-cut positions on EU integration visible. The most obvious option for a medium is to publish a commentary put forward by its own journalists. A more hidden way of making specific positions prominent is associated with news media's gatekeeper role, which shapes the reporting section. In their role as gatekeepers, media must decide not only which issues to raise on the agenda but also how to present them. They often do so by selecting speakers from the political or societal arena that put forward specific frames and evaluations.

For most issues discussed in society, it might be sufficient to study whether news media support or oppose a specific policy and the associated authorities in their editorial and news sections. However, in cases in which policy issues become connected to the more abstract level of polity contestation (which is the case for EU contestation), we need to develop a more fine-grained understanding of position-taking. In such cases concrete questions of the pros and cons regarding specific policy issues (e.g., more or less welfare state measures) are connected to larger questions referring to the institutional set-up (e.g., is it appropriate to decide these questions on the national/EU level?) Finally, in the case of EU integration, a third 
object of evaluation comes into play (Easton 1975): the political community. Political communities have an institutional base, but just as importantly need to be constructed in citizens' minds (Andersen 1991). Consequently, position-taking on the EU is a threefold concept (Easton 1975) referring to (1) support and opposition formulated towards concrete policy issues and the associated authorities; (2) evaluations of the regime or the polity of the EU (of which negative evaluations are termed Euroscepticsm and conceived as 'genuine opposition to European integration’ [Harmsen 2010: 336; emphasis in original]); and (3) portrayals of a political community which might support or oppose a community stretching beyond the nation state.

Research on media’s position-taking regarding the EU has thus far focused primarily on news sections conceiving them as a forum in which evaluative claims of various speakers become visible (e.g., Kriesi et al. (2006); Statham et al. (2010)). These studies then conclude that specific types of speakers, such as the radical left and right, put forward more anti-EU positions or that some (Eurosceptic) parties get significantly more coverage in the news media compared to their electoral status (Gattermann and Vasilopoulou 2015). Other studies analyse the reporting section to identify the media's general tone towards Europe. These studies show that before Maastricht, EU coverage was low but, on the evaluative side, balanced or slightly pro-European (Lloyd and Marconi 2014). Since then, the visibility of the EU, its institutions and European policies has increased (Koopmans et al. [2010]; Wessler et al. 2008), with the tone becoming more negative (Schuck et al. 2011). Hereby, the negative portrayal of the EU seems to outnumber positive references (Norris 2000).

The absence of more detailed research on media position-taking regarding Europe is puzzling, considering that media are often blamed to be at the root of the current Eurosceptic public opinion. Research, thereby, is hampered at least in a threefold manner. First, media's position-taking regarding the EU often applies general measures on the tone towards Europe and thereby hardly distinguish which aspects of the EU are criticized or supported. Second, research has focused on news section when studying positions towards Europe while surprisingly neglecting to separately analyse editorials (for an exception, see Pfetsch 
et al. [2010]). Third, research is lacking on whether the editorial stances also colour media's selection routines in the news section. This possible interrelation between editorials and news is dealt with in the following.

\section{The synchronization of position-taking in commentaries and news}

Normative ideas of professional journalism call for the strict separation of facts and opinions. This means that media's positions are legitimately voiced in the editorial section, whereas media should demonstrate a neutral, unbiased way of reporting in their news sections (Bennett 1988) and thus serve here as faithful chroniclers (Neidhardt 1994). Kahn and Kenney (2002: 381) speak of a ‘wall of separation’ between editorials and news that characterizes a professional and impartial press.

However, empirical research shows that these two distinct roles of mass media are often intertwined: there is evidence that newspapers' editorial lines also influence the selection decisions within the news section by granting a more prominent role to actors who put forward similar positions, arguments or frames (e.g., Bachl and Vögele 2013; Berkel 2006; Hagen 1993). For example, Hagen (1993: 334) finds in his analysis of the German census debate that 'the direction of the arguments published in the newspapers were heavily influenced by editorial stance'. Brettschneider and Wagner (2008) show for the British Sun that explicit voting endorsements are reflected in the reporting section. Kahn and Kenney (2002) show that even in the United States (US), which is often regarded as having one of the most impartial and liberal media systems (Hallin and Mancini 2004), newspaper coverage during Senatorial campaigns is slanted in favour of the candidate the newspaper endorses in its editorial section. A similar effect was observed by Peake (2007) for presidential elections in the US.

This breaking-up of the ‘wall of separation’ (Kahn and Kenney 2002) between editorials and news is captured by the notion of 'synchronization' (Eilders 1999; Schönbach 1977), which will be used in this article, as well as by 'political parallelism’ (Berkel 2006), ‘editorial slant’ (Kahn and Kenney 2002), ‘opportune witnesses’ (Hagen 1993) or ‘instrumental actualization’ (Kepplinger et al. 1991). 
All of these concepts claim that (a) there is a close correspondence between news and editorials, and that (b) this correspondence is driven by the editorial agenda of the newspaper.

Prerequisite for interpreting a correspondence between news and editorials as synchronization is that such correspondence is not merely a reflection of a dominant and consonant opinion climate within a country, but is driven by editorial positions. To avoid interpreting media being in line with a consonant opinion climate as editorial-driven synchronization, three approaches can be distinguished. First, no consonant opinion climate exists if national media outlets present conflicting ideas in their editorial sections which - if synchronization occurs - are reflected in their news sections. This is the most common approach to study synchronization (e.g., Hagen 1993; Tresch 2012). Second, the lack of a consonant opinion climate can also be seen on the national political level. In cases where the political elites put forward diverging positions and the media prefer one side of these positions while neglecting the opposing views, we may also interpret a correspondence between editorials and news as synchronization. Following this approach, it is possible to study synchronization looking at one media outlet only. Additionally, however, we need to show that conflict prevails among the national political elite (what is mostly done in national election contexts, e.g., Brettschneider and Wagner [2008]). Third, the lack of a consonant opinion climate is indicated by a divide between national media outlets and national political elites. In such settings in which national media raise their voices against national political elites, synchronization can hardly be tested on the national level. Yet, in transnational settings like the EU context, synchronization may still occur as media select transnational speakers to support their editorial positions. To our knowledge this approach has not yet been applied in synchronization studies. For the described three settings in which synchronization might be observed, we expect:

H1a: The more pro-/anti-EU a newspaper's editorial position, the more pro-/anti-EU voices we find in its news section. 
The strength of synchronization between editorials and news is likely to depend on the media system. Hallin and Mancini (2004) have identified three types of Western media systems: the polarized pluralist; the democratic corporatist; and the liberal system; which are distinguished - among others - according to the strength of political parallelism and of journalistic professionalism. Systems with high political parallelism are characterized by strong connections between the media and political actors, with the media willing to become involved in political advocacy. Political parallelism might thus be expected to foster media's position-taking. However, whether this position-taking leads to synchronization between editorials and news depends on the degree of journalistic professionalism. In media systems in which journalistic professionalism is high, objectivity and political neutrality are valued, which hinders strong synchronization. As polarized pluralist media systems are characterized by high political parallelism and weak journalistic professionalism, whereas liberal models adhere to low political parallelism and strong professionalism, with the democratic corporatist systems in-between (political parallelism but strong professionalism), we expect:

H1b: The synchronization of editorials and news is most pronounced in countries with high levels of political parallelism and low levels of journalistic professionalization - that is, in polarized pluralist systems.

Thus far, however, synchronization between editorials and news has been studied in the course of national debates or elections (for an exception, see Berkel [2006] and Tresch [2012]). Here, left-leaning media primarily refer to left-leaning national sources and ideas, whereas the contrary applies to right-leaning media. In the course of transnationalization processes, the most important being EU integration, the monopoly of national actors in being able to raise their voices in news media's reporting sections is challenged. Transnational political integration goes along with an abundance of transnational speakers (from the supranational level or from other involved [member] states) that might be selected by national media and thus be included in national debates. Research on the Europeanization of public spheres clearly shows 
that national mass media - to different degrees and under specific circumstances - do grant actors from outside the nation state a voice (e.g., Adam 2016).

Specifically, in the EU context there is very little research on synchronization. One exception is Berkel (2006), who investigated the media response in other EU member states to the election of right-wing populist Haider in Austria. She finds strong evidence of synchronization, as newspapers also support their editorial lines through the selection of congruent sources in the reporting section. However, contrary to this finding, Tresch (2012), in an analysis of a referendum on EU issues in Switzerland, does not find support for the synchronization of editorials and news regarding the selected sources, but does find evidence that the use of specifically selected frames supports the editorial stances.

However, none of these studies focuses on the specifics of EU contestation - that is, the potential inclusion of transnational speakers in the media's reporting. Consequently, it remains unclear whether and to what degree synchronization between editorials and news stretches beyond national speakers, under which conditions and which new types of synchronization might result from the inclusion of transnational actors.

Two arguments are relevant why synchronization might differ depending on whether the media selects national or transnational speakers. First, synchronization is closely associated with long-lasting traditional bonds between national politics and national news media and thus might be stronger when national voices are selected. Second, research has shown that the transnational speakers who are given a voice in national media are usually powerful elite, most likely governmental actors (Koopmans 2007). It is thus the power and status, and less so the position, that seems to drive the selection processes for transnational speakers. We therefore expect:

H2a: The synchronization of editorials and news is stronger if national voices are selected compared to transnational ones. 
However, the synchronization of editorials and transnational voices in the news might also be conditional. In cases where all ideological positions are voiced by important and prominent national political speakers, media have few incentives to select transnational actors to support their editorial line. In this case, they are likely to select transnational actors based on their power and status. However, in cases where the editorial line of a newspaper is only weakly supported within the national boundaries, transnational voices may open up new possibilities for synchronization of evaluations. We thus expect:

H2b: The less a newspaper's EU position is supported by national political speakers, the more the newspaper uses transnational speakers to make the own position heard.

Whereas H2b asks whether newspapers grant voice to transnational actors that position-wise support their editorial line, the following hypothesis is intended to capture synchronization by looking at the quantity of transnational speakers in the news section (independent of their positions). This latter synchronization approach thus looks for a correspondence between editorial positions and the portrayed relevant political community in the news section. If transnational speakers strongly turn visible, a newspaper portrays a political community in which national and transnational spheres are intertwined. If, however, transnational speakers are hardly included in debates, newspapers depict a self-sufficing national community in which the transnational level is irrelevant. We thus expect:

H2c: The more (less) pro-EU a newspaper's editorial position, the more (less) the newspaper is open to grant attention to transnational speakers.

Consequently, for Eurosceptic newspapers in a pro-European environment, our hypotheses suggest that position-wise newspapers use transnational actors as substitute for the lack of national input, whereas quantitatively they allow only few transnational actors to raise their voices as they seek to put forward a national confined political community. 


\section{Case selection, data and methods}

To study media's position-taking regarding EU integration and the possible interrelation between positiontaking in commentaries and news, we focus on quality newspapers' communication in the run-up to the 2014 EP elections in seven countries, namely Austria (AUS), France (F), Germany (GER), Greece GR), The Netherlands (NL), Portugal (POR) and the United Kingdom (UK). We have chosen these countries as they differ regarding their level of political parallelism and journalistic professionalization (H1b) and regarding the political input on the side of political elites (H2b). High parallelism is combined with low professionalization in the polarized pluralist countries (GR, POR, F). This is contrasted by the democratic corporatist countries (AUS, GER, NL) and the liberal country (UK), which are characterized by higher levels of journalistic professionalization and partly also by lower levels of political parallelism (Hallin and Mancini 2004). Political input is measured based on a content analysis of parties' press releases spanning the same time period as the media analysis (see Adam et al. 2016). Figure 1 shows variation of elite input among the selected countries concerning party's evaluation of the EU (see the Online Appendix for details of the evaluation index).

For our study, we analyse two quality newspapers per country, one left- and one right-leaning (see the Online Appendix) 12 weeks preceding the 2014 EP elections. We rely on the national quality press because it contains most coverage of EU integration, which makes these papers important agenda-setters on EU issues. We collected all articles from the political and editorial sections that referred to European policies, European institutions, European politicians and/or the EP elections at least twice (for the search string, see the online appendix). To limit the workload, we rotated the left- and right-leaning papers on a daily basis. Our search resulted in 3,733 articles. Based on a quantitative content analysis (for the detailed codebook, see Maier et al. [2014]) we identified active speakers who put forward their political statements. Up to three such speakers were coded per article, whereas the journalist is coded as the single speaker in the editorial section. The basis of the following analysis entails 3,010 articles with at least one speaker, 
resulting in 4,978 speakers. To test H2a-c, we differentiate these active speakers into national and transnational ones. National speakers include political and non-political actors from a country's own nation state as well as all journalists of its own newspaper (independent of whether they are located at the national editorial office or abroad) whereas transnational speakers come from other (EU) countries or from the transnational / EU level.

Based on these speakers, we measure position taking towards EU integration as follows. First, we analyse whether a (national and transnational) speaker supports or criticizes concrete EU policies and authorities (i.e., politicians or institutions, EUconcrete). Second, support or opposition can be directed towards the general and fundamental idea of EU integration and the regime as such (EUfund). Both indicators differentiate between four categories: positive; negative; balanced (as many positive as negative evaluations); and no evaluation. Based on the first three categories, we calculate an EU evaluation index (for the formula, see the online appendix) per medium that ranges from -1 (strong EU opposition) to +1 (strong EU support). The index is based on all statements that contain evaluations $(n=206$ in editorials and $n=1,021$ in the news section), and it gives added weight to the more fundamental evaluations on EU integration as such compared to evaluations referring to concrete policies or actors. This serves as the central measure for synchronization in our paper. Third, to analyse whether media support or oppose a specific depiction of a political community in line with their editorial stances (H2c), we study the share of transnational speakers that are granted a voice in the news section (speakers: $\mathrm{N}=4,476$ ).

To ensure the quality of coding, all 21 coders participated in a comprehensive training programme followed by (researcher-coder) reliability tests of at least 25 speakers each. We tested the coding reliability using the Holsti formula and Krippendorff's Alpha coefficient whenever possible or useful. With average Krippendorf Alpha scores of 0.73 for the identification of speakers and with average Holsti scores of 0.83 for the EU evaluations, the reliability tests delivered satisfactory results. ${ }^{\mathrm{i}}$ 
We use correlations between editorials and news to analyse synchronization despite their limitations: They cannot capture causality and struggle with limited case numbers ( $\mathrm{N}=14$ newspapers). Therefore, we have conducted robustness checks where possible. Hereby, we have recalculated the correlations omitting the most extreme cases (outlier analysis) and have conducted a Jackknife and bootstrap sensitivity analysis. All types of analyses point to the robustness of our results (see online appendix), but also to large 95 per cent confidence intervals.

Finally, we have to critically evaluate whether a possible fit between editorials and news can be interpreted as a sign of synchronization or whether it might be a mere reflection of a dominant opinion climate. Figure 1 summarizes the editorial and political elite positions on EU integration in the seven countries under study. The index varies between -1 (strong EU opposition) and +1 (strong EU support) and is based on media editorials as well as parties’ press releases (also issued 12 weeks preceding the EP elections). A first inspection of Figure 1 shows clearly that a dominant opinion climate prevails in none of our countries. A more detailed look allows us to distinguish three groups. First, in the UK and to a lesser degree also in Greece, conflict is reflected in the editorial agendas of the selected newspapers. In addition, conflict also runs among political actors. For these countries, classical synchronization studies are possible. Second, in Austria, France and Germany, conflict on EU integration is carried by political elites: strong EU supporters (e.g., Österreichische Volkspartei (ÖVP), Mouvement démocrate (MoDem), Freie Demokratische Partei (FDP)) are challenged by EU opponents (Freiheitliche Partei Österreichs (FPÖ), Bündnis Zukunft Österreich (BZÖ), Front National (FN), Linke, Alternative für Deutschland (AFD)) with media favouring the pro-side in Austria and Germany and the con-side in France. Finally, conflict in Portugal and the Netherlands runs primarily between national political elites and the newspapers. In such settings, synchronization might occur by selecting transnational speakers. 
Figure 1: National parties' supply of EU positions and newspapers' editorial EU positions.

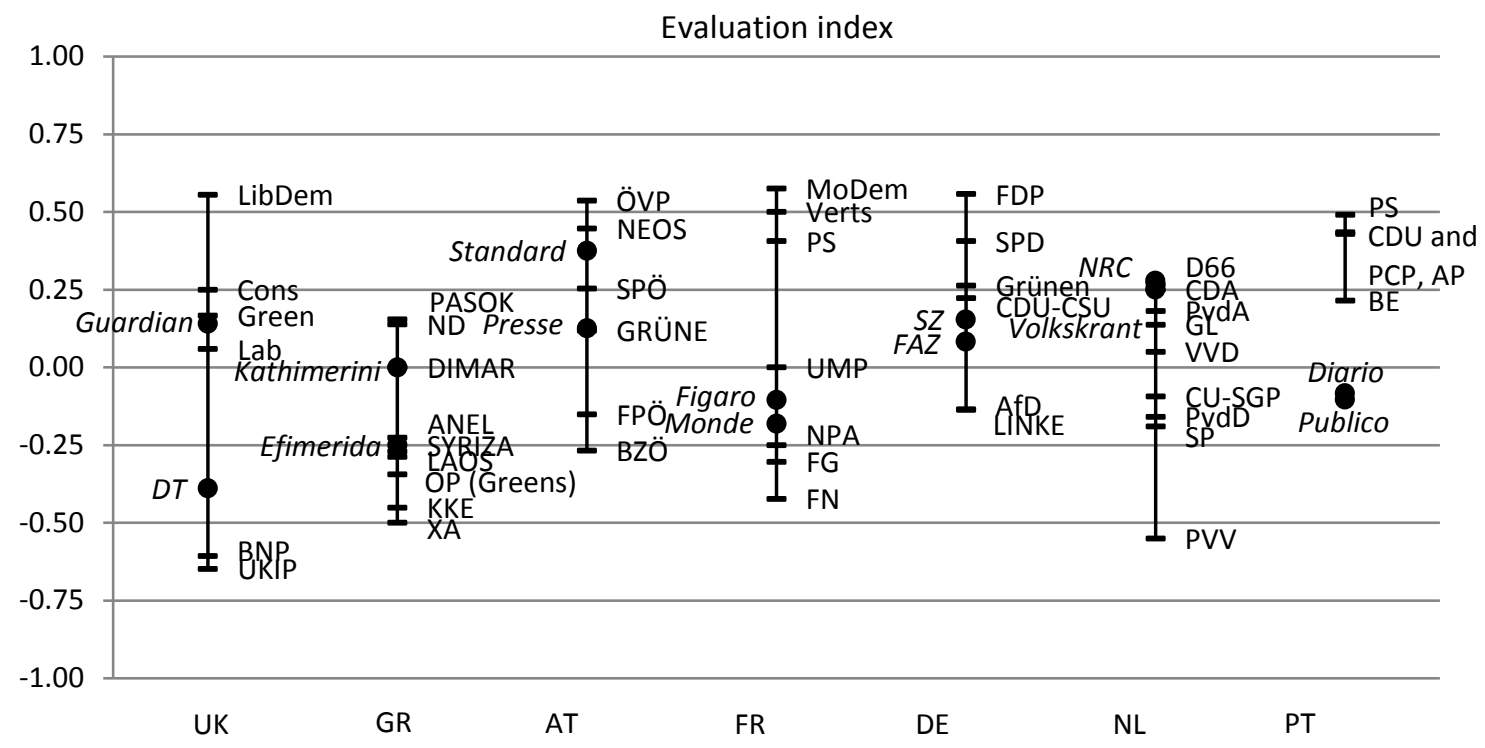

Basis: EU-related press release/editorials containing an EU evaluation: UK (N = 143/25); GR (N = 209/50); AT ( $=546 / 20) ;$ FR $(\mathrm{N}=120 / 30) ; \mathrm{DE}(\mathrm{N}=181 / 25) ; \mathrm{NL}(\mathrm{N}=127 / 23) ; \mathrm{PT}(\mathrm{N}=240 / 33)$.

\section{Results}

\section{Synchronization between commentaries and news on EU integration}

Before analysing whether a newspaper's editorial position regarding the EU is related to its selection decisions in the news section, we show whether, how often and in which way the analysed mass media evaluate the EU in their editorials and news sections (see Figure A1 and A2 in the online appendix). The results show first that evaluations are important but not dominating reporting and commentating about the EU. On average it is 41.0 per cent of the commentaries and 22.8 per cent of the speakers raising their voices in the news section that clearly evaluate the EU. Second, evaluations thereby are primarily directed towards concrete EU policy issues and authorities. Probably as expected in the current crisis, these concrete evaluations are negative in editorials and news across all newspapers except for the editorial positions voiced in the Standard in Austria and Handelsblad in The Netherlands. Third, if evaluations are geared towards the EU 
as such, newspapers in their editorials, as well as in their news sections, defend the idea of EU integration with positive regime evaluations outnumbering the negative ones. The only exception here is The Telegraph (UK), which opposes EU integration as such in its editorial as well as its news section.

To test whether a newspaper's position-taking in editorials and news is related (H1a), we compare the overall EU evaluation (evaluation index) put forward in a newspaper's editorial and news section. Figure 2 summarizes the results and confirms our first hypothesis (H1a), showing that the more pro-(contra-) EU a newspaper's editorial position, the more pro-(contra-) EU voices we find in its news section. The correlation between newspapers' editorial positions on EU integration and their selection of voices in the news sections is strong and significant $(r=0.68, \mathrm{p}<0.01)$.

Figure 2: Synchronization of newspapers’ positions in editorials and news.

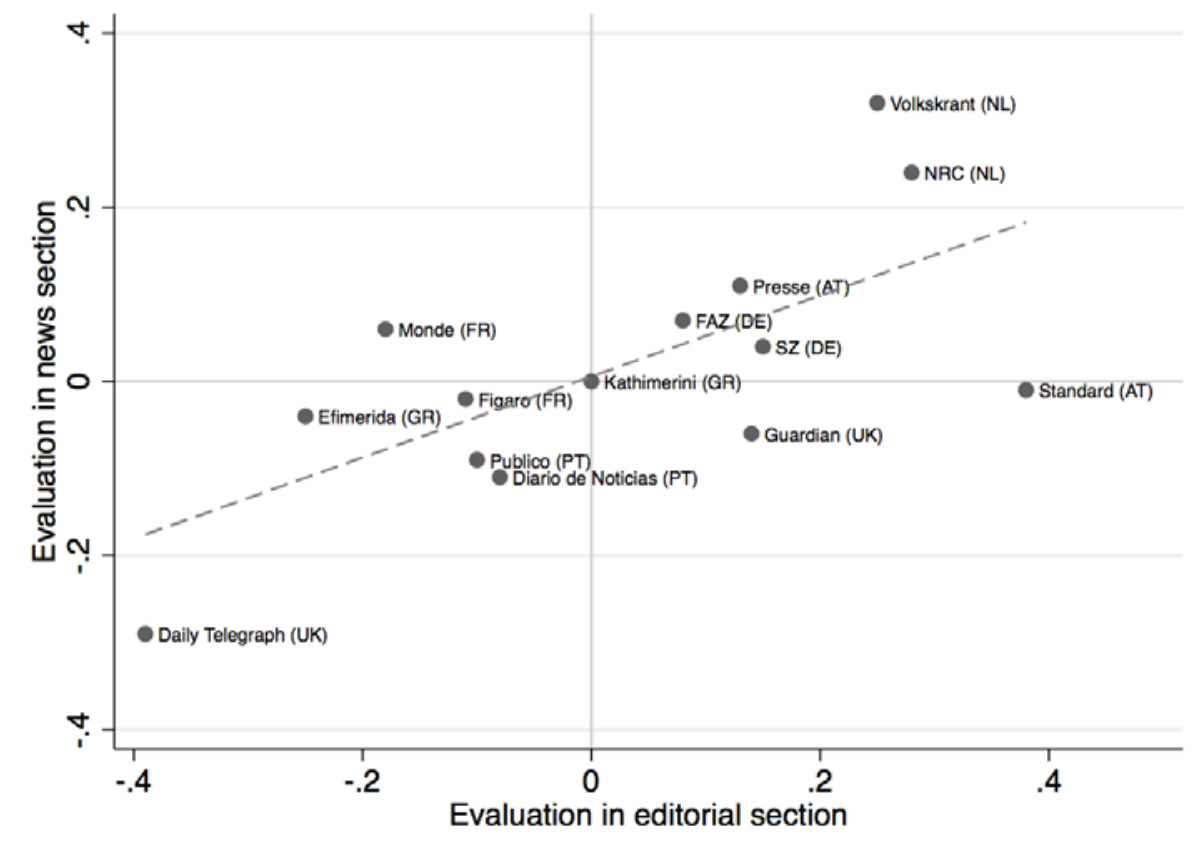

Basis: all evaluated statements coded; $N=206$ editorials; $N=1,021$ speakers in the news section. 
Following H1b, we expect that synchronization is most pronounced in countries with high levels of political parallelism and low levels of journalistic professionalization - that is, in the polarized pluralist countries (GR, POR, F). Our data lead us to reject this hypothesis. Contrary to our expectations, synchronization occurs primarily in democratic corporatist countries (AUS, GER, NL) and the liberal country (UK), which can be seen in Figure A3 in the online appendix. We have abstained from using correlations here owing to the small case numbers.

\section{The role of transnational speakers in the synchronization between editorials and news on EU inte- gration}

To analyse whether a newspaper's editorial position is more strongly associated with the selection of national voices or transnational voices (H2a), we compare the strength of Pearson correlations between the editorial positions on EU integration and the positions voiced (a) by national and (b) by transnational speakers (e.g., government actors from another country, EU Commission or EU parliamentarians) in the respective news sections. An analysis of synchronization between position-taking in editorials and of national voices in news sections shows a strong Pearson correlation of $0.62(\mathrm{p}<0.05)$, whereas this correlation is lower and not significant for transnational voices $(r=0.39, \mathrm{p}=\mathrm{n} . \mathrm{s}$.$) . These findings suggest that newspapers$ actively select speakers from the national realm that support their editorial lines, whereas the congruence of transnational speakers' positions to the newspaper's own editorial line is of less importance, which causes us to confirm H2a. A visual display of these results is also shown in the online appendix (Figures A4 and A5a).

Although we can reject a general synchronization between editorials and the positions of transnational speakers selected in the news sections, we seek to unravel the conditional nature of such transnational synchronizations. We expect synchronization regarding transnational speakers to be especially strong in those cases in which a newspaper's EU position is not supported by national political speakers (H2b), which is the case in Portugal and to a lesser degree in The Netherlands (see Figure 1). In Portugal, all parties 
strongly support EU integration, whereas Diario de Noticias and Publico tend towards EU-critical positions. The contrary case applies to The Netherlands: here, it is the pro-EU positions of both newspapers that are contrasted by party positions that tend towards the EU-critical side.

In all cases our data support the idea of synchronization: it is the Portuguese papers which tend slightly towards the EU-critical side in their editorials (evaluation index: -0.08 for Diario de Noticias; -0.10 for Publico) and also give voice to EU-critical actors although the national parties’ campaigns are clearly pro-European (Diario de Noticias: -0.11 for national and -0.14 for transnational speakers; Publico: -0.08 for national and -0.14 for transnational speakers). In the Dutch case, we can observe the opposite: despite the prevalence of EU-critical positions on the side of national parties, newspapers not only voice EU-support in their editorials but also select EU-supportive voices in their news sections (NRC Handelsblad: 0.28 for editorials; 0.15 for national; and .30 for transnational speakers; de Volkskrant: 0.25 for editorials; 0.38 for national; and 0.14 for transnational speakers). Regarding our substitute thesis, two observations are noteworthy. First, even when supportive input from national parties is lacking, newspapers find voices on the national level that support their editorial lines. From this perspective, transnational speakers do not need to compensate for a complete lack of national input. Second, however, in three of our four cases (the exception being de Volkskrant), transnational speakers are used to fill the gap on the national level: transnational voices cited in the news sections do put forward more extreme EU positions than national speakers - all of them pointing in the direction of the respective editorial lines.

Finally, we compare the strength of synchronization regarding transnational voices of those newspapers whose editorial lines are weakly supported on the national level (in POR and NL) to those newspapers whose editorial lines are fully supported (in AUS, F, GER, GR and the UK)? A visual inspection clearly supports our idea (Figure A5b in the Online Appendix): newspapers exploit the transnational environment by selectively granting a voice to those transnational speakers that support their own editorial lines in situations where a newspaper puts forward a position against its own national political context. 
Figure 3 finally shows whether the editorial agenda also impacts a newspaper's openness to grant attention to transnational speakers (reflecting a country's portrayal of the relevant political community H2c). It shows that the share of transnational speakers in the news related to EU integration varies greatly. Transnational speakers have a share of around 30 per cent in Diario de Noticias, Publico and The Daily Telegraph, whereas their share amounts to more than 60 per cent in the two German newspapers, in the Presse and NRC. This variation in openness towards transnational speakers is closely related to the editorial position of a newspaper. Those newspapers which oppose EU integration tend towards national closure, whereas those with a pro-European position more strongly grant transnational speakers a voice. The relation is moderately strong and highly significant $(r=0.59, \mathrm{p}<0.05)$ and grants support to H2c.

Figure 3: Synchronization of newspapers' positions in editorials and their openness towards transnational speakers.

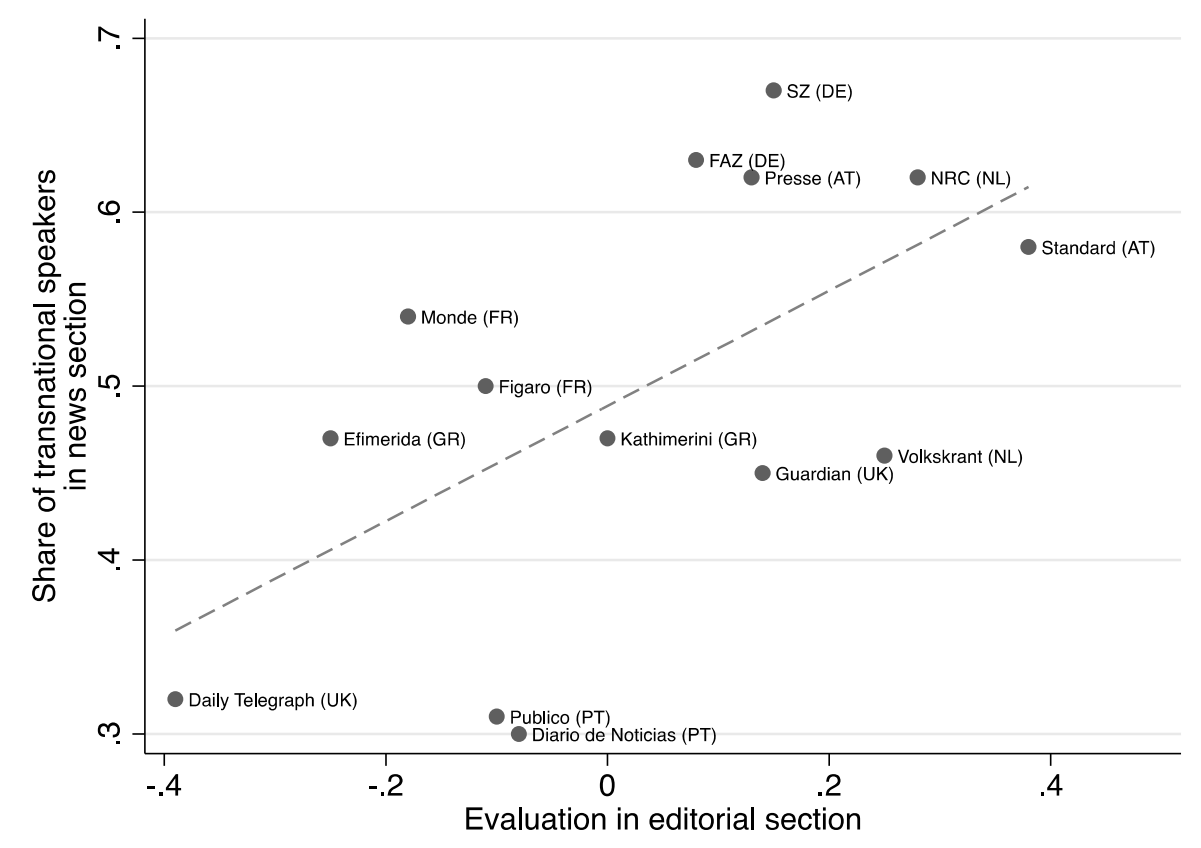

Basis: $\mathrm{N}=206$ editorials (evaluated), $\mathrm{N}=4,476$ speakers in the news section (with and without position), of which 2,202 are transnational speakers. 


\section{Conclusion}

News media’s position-taking regarding the EU has four characteristics. First, media across Europe voice mostly negative evaluations on concrete EU policies and authorities (except for the Austrian Standard and the Dutch NRC Handelsblad), whereas they defend the idea of EU integration (except for the British Telegraph). Second, position-taking is not limited to the editorial pages. Instead, our results point towards synchronization between newspapers' editorials and their selection decisions within the news sections. However, contrary to our expectations, the strength of such synchronization cannot be explained by the type of media system: polarized-pluralist systems do not show more but rather fewer synchronization tendencies. Third, synchronization regarding the evaluation of EU authorities and the EU regime is limited to the selection of national voices. However, under the condition that news media put forward an editorial line hardly supported by such national political elites, media actively exploit the transnational environment by selecting transnational voices in line with their editorial positions. Finally, news media’s synchronized position-taking regarding EU integration is also reflected in the portrayal of a political community. Media that oppose EU integration in their editorials also strongly privilege national voices on a quantitative level in their news sections, and thus portray a self-sufficing national community.

It would be misleading to claim that all media are equally synchronized. Instead, what our results clearly show is that synchronization varies in strength and in form (i.e. being observed in policy/polity position congruence or in congruence towards the political community portrayed). Strong synchronization requires clear-cut editorial positions which are then strongly reflected in the news sections. From a normative perspective, these are the cases where media do not live up to the ideal of a clear-cut 'wall of separation' (Kahn and Kenney 2002) between editorials and news. In our empirical data, the Daily Telegraph (UK) and the $N R C$ (NL) are the most strongly synchronized newspapers: they not only put forward clear-cut EU positions in their editorials, but also take these up in their policy / polity evaluations in the news sections and their community portrayals. The other three cases which are characterized by strong editorial positions (Volkskrant, NL; Standard, AUS; Efimerida, GR) differ in the form of synchronization as they either reflect 
these positions in their policy/ polity evaluations or in their community portrayals and as such show a more moderate form of synchronization. Most of the other newspapers show weak forms of synchronization: their slightly one-sided editorial positions on Europe are reflected in slightly biased positions put forward in the news sections and in the respective community portrayals. However, our study also reveals media that on first sight are not in line with synchronization expectations, the clearest example being the Guardian (UK): despite its EU-friendly editorial line, it is neither open to non-national speakers nor does it tend towards EU-supportive positions in its news section. This clearly indicates that synchronization is only one factor among others (e.g., the general opinion climate) that shapes media’s position taking.

Our study speaks to four areas of research. First, we show that the concept of synchronization also applies to EU politics, is valid (in different strength and forms) for many countries and also stretches to the selection of transnational actors. These transnational actors are used position-wise as substitutes for the lack of national input, and they are used attention-wise to put forward a portrayal of the political community that goes along with the editorial position on EU integration. However, contrary to our expectations, variations in the degree of synchronization across countries could hardly be explained by a reliance on Hallin and Mancini’s (2004) media system typology. Structural media system factors as identified by Hallin and Mancini thus do not travel easily to the cultural level of concrete media behaviour, what once more `calls into question the assumption of a close correspondence between structure and culture` (Esser 2008: 425), a challenge for future comparative research.

Second, we identify newspapers’ editorial positions as drivers or break blocks for the Europeanization of public spheres. Such Europeanization requires that national arenas open up for the inclusion of speakers from the EU or other member countries (Koopmans and Erbe 2004) or that national arenas discuss similar issues at the same time with the same reference frame (Eder and Kantner 2000). Both indicators of Europeanization processes are affected by newspapers' editorial positions: it is pro-European papers that grant transnational speakers a voice, and it is newspapers in line with national political elites that do not select transnational speakers to strengthen their own position. Instead, these papers follow a selection logic 
driven by the news value of power and prestige, which makes it likely that news media across countries focus on similar transnational speakers.

Third, our results speak to the role of media in spreading Euroscepticism across the continent. Euroscepticism, defined as principled opposition to the regime of EU integration, is rare in Europe's quality media - with The Telegraph from the UK being the only medium in our sample in which such fundamental opposition is put forward. However, critique towards concrete EU policies and authorities/institutions is the daily routine in Europe's news media (as it is towards national authorities and institutions). Therefore, such concrete criticism is much more frequent than any discussion of the principles of EU integration. Although such critique should not be conflated with Euroscepticism, it is an open question as to how such frequent critique on concrete matters of EU integration impacts citizens’ perceptions of the Union.

Finally, by connecting the political input to the media output, we have clearly shown that media are - under specific circumstances - more than a direct reflection of elite communication. In two out of our seven countries (POR and NL) news media take positions that are not in line with the national parties' stances on EU integration. This finding might seem surprising, given the prominence of concepts such as indexing (Bennett 1990), which stress the elite dependency of the media. The time thus seems ripe to further our understanding on the conditions that lead the media to counter-stand national mainstream elites and thereby strategically use transnational environments.

In the end, a critique of our study might claim that an analysis of traditional newspapers is outdated given the fact that information presentation and consumption is moving online. However, such critique overlooks that traditional media are still important in times of online news consumption. It is primarily mass media content that is used for political information purposes online and that has shown to be quite similar to its offline counterpart (Oschatz et al. 2014). Further, our study on traditional media contributes to one of the most widely discussed issues in political communication in the online world - the phenomenon of one-sided news that allows for selective news consumption. This one-sidedness of news which has been 
primarily associated in recent times with so-called 'filter bubbles' or 'echo chambers' in the online world (e.g., Sunstein 2009) can at least partly also be observed in traditional news media: it is the readers of some of Europe's most prestigious news outlets that are exposed to one-sided coverage about Europe not only in the editorials but in the news sections as well. 


\section{Biographical note}

Silke Adam is Professor of Communication Science at the University of Bern, Switzerland

Beatrice Eugster is Post-Doctoral Researcher at the Institute of Communication and Media Science at the University of Bern, Switzerland

Eva Antl-Wittenberg is $\mathrm{PhD}$ student at the Institute of Communication Psychology and Media Pedagogics at the University of Koblenz-Landau, Germany

Michaela Maier is Professor of Applied Communication Psychology at the University of Koblenz-Landau, Germany.

Rachid Azrout is Post-Doctoral Researcher at the Amsterdam School of Communication Research, Netherlands

Judith Möller is Post-Doctoral Researcher at the Amsterdam School of Communication Research, Netherlands

Claes de Vreese is Professor of Political Communication at the Amsterdam School of Communication Research, Netherlands

Sylvia Kritzinger is Professor for Methods in the Social Sciences at the University of Vienna, Austria.

\section{Address for correspondence}

Prof. Silke Adam

Fabrikstr. 8

3008 Bern

Switzerland

Email: silke.adam@ikmb.unibe.ch

Phone: 0041 / 316314848 


\section{Funding details}

This work was supported by the Swiss National Science Foundation (100017E-144592/1) and the German Science Foundation (MA 2244/5-1).

\section{Notes}

${ }^{\mathrm{i}}$ A detailed overview of the reliability scores is available from the authors upon request. 


\section{References}

Adam, S. (2016) ‘European Public Sphere’, in G. Mazzoleni (ed.), International Encyclopedia of Political Communication, Chichester, UK: John Wiley \& Sons, Inc., pp. 1-9.

Adam, S. et al. (2016) ,Strategies of pro-EU parties in the face of a Eurosceptic challenge', European Union Politics, 0(0): 1-23.

Andersen, B. (1991) Imagined Communities. Reflections on the Origin and Spread of Nationalism, London/New York: Verso.

Bachl, M., and Vögele, C. (2013) 'Guttenbergs Zeugen? Eine Replikation und Erweiterung von Hagens (1992) ‘Die opportunen Zeugen’ anhand der Berichterstattung über Karl-Theodor zu Guttenberg im Kontext der Plagiatsaffäre', Medien \& Kommunikationswissenschaft 61(3): 345-367.

Bennett, L.W. (1988) News, the Politics of Illusion, New York: Longman.

Bennett, L.W. (1990) 'Toward a theory of press-state relations in the U.S.', Journal of Communication 40(2): 103-125.

Berkel, B. (2006) 'Political parallelism in news and commentaries on the Haider conflict : a comparative analysis of Austrian, British, German and French quality newspapers’, Communications: The European Journal of Communication Research 31(1): 85-104.

Bijsmans, P. (2015) 'Media and Euroscepticism: exploring unchartered territory', Paper presented at the UACES Conference, Bilbao, 7-9 September.

Brettschneider, F., and Wagner, B. (2008) ‘And the winner should be... Explizite und implizite Wahlempfehlungen in der Bild-Zeitung und der Sun', in B. Pfetsch and S. Adam (eds), Massenmedien als politische Akteure, Wiesbaden: VS, pp. 225-244. 
Easton, D. (1975) 'A re-assessment of the concept of political support', British Journal of Political Science 5: 435-457.

Eder, K., and Kantner, C. (2000) ‘Transnationale Resonanzstrukturen in Europa. Eine Kritik der Rede vom Öffentlichkeitsdefizit’, Kölner Zeitschrift für Soziologie und Sozialpsychologie, Sonderheft 40: 306-331.

Eilders, C. (1999) 'Synchronization of issue agendas in news and editorials of the prestige press in Germany', Communications: The European Journal of Communication Research 24(3): 301-328.

Esser, F. (2008) 'Dimensions of Political News Cultures: Sound Bites and Image Bite News in France, Germany, Great Britain, and the United States’, Press / Politics, 13(4): 401-428.

Gattermann, K., and Vasilopoulou, S. (2015) ‘Absent yet popular? Explaining news visibility of members of the European Parliament', European Journal of Political Research 54(1): 121-140.

Hagen, L.M. (1993) 'Opportune witnesses. An analysis of balance in the selection of sources und arguments in the leading German newspapers' coverage of the census issue', European Journal of Communication 8: 317-343.

Hallin, D.C., and Mancini, P. (2004) Comparing Media Systems. Three Models of Media and Politics, Cambridge: Cambridge University Press.

Harmsen, R. (2010) 'Concluding comment: on understanding the relationship between populism and Euroscepticism', Perspectives on European Politics and Society 11(3): 333-341.

Kahn, K.F., and Kenney, P.J. (2002) 'The slant of the news: how editorial endorsements influence campaign coverage and citizens' views of candidates', American Political Science Review 96(2): 381394. 
Kepplinger, H.M., Brosius, H.-B., and Staab, J. (1991) 'Instrumental actualization: a theory of mediated conflicts', European Journal of Communication 6(3): 263-290.

Koopmans, R. (2007) 'Who inhabits the European public sphere? Winners and losers, supporters and opponents in Europeanised political debates', European Journal of Political Research 46(2): 183210.

Koopmans, R., and Erbe, J. (2004) 'Towards a European public sphere?’, Innovation 17(2): 92-118.

Koopmans, R., Erbe, J., and Meyer, M.F. (2010) 'The Europeanization of public spheres: comparisons across issues, time, and countries', in R. Koopmans and P. Statham (eds), The Making of a European Public Sphere. Media Discourse and Political Contention, New York: Cambridge University Press, pp. 63-96.

Kriesi, H. et al. (2006) 'Globalization and the transformation of the national political space: six European countries compared', European Journal of Political Research 45: 921-956.

Lloyd, J., and Marconi, C. (2014) Reporting the EU. News, Media and the European Institutions, London: IB Tauris.

Maier, M. et al. (2014) 'Politicization of EU integration. Codebook for a content analysis of media and party communication', available at http://www.ikmb.unibe.ch/codebuch_eu2014 (accessed 13 July 2016).

Neidhardt, F. (1994) ‘Öffentlichkeit, öffentliche Meinung, soziale Bewegungen’, Kölner Zeitschrift für Soziologie und Sozialpsychologie, Sonderheft 34: 7-41.

Norris, P. (2000) A Virtuous Circle: Political Communication in Post-Industrial Democracies, Cambridge: Cambridge University Press. 
Oschatz, C., Maurer, M., and Hassler, J. (2014) ‘(R)Evolution der Politikberichterstattung im Medienwandel? Die Inhalte von nachrichtenjournalistischen Online- und Offline-Angeboten im Vergleich’, Medien \& Kommunikationswissenschaft 62(1): 25-41.

Page, B. (1996) ‘The mass media as political actors', Political Science and Politics 29(1): 20-25.

Peake, J.S. (2007) 'Presidents and front-page news: how America's newspapers cover the Bush administration', The Harvard International Journal of Press/Politics 12(4): 52-70.

Pfetsch, B., Adam, S., and Eschner, B. (2010) ,The Media's Voice over Europe: Issue Salience, Openness, and Conflict Lines in Editorials', in R. Koopmans and P. Statham (eds), The Making of a European Public Sphere, Cambridge: Cambridge University Press, pp. 151-170.

Schönbach, K. (1977) Trennung von Nachricht und Meinung. Empirische Untersuchung eines journalistischen Qualitätskriteriums, Freiburg: Alber.

Schuck, A.R.T. et al. (2011). 'Media visibility and framing of the European Parliamentary Elections 2009: A media content analysis in 27 countries’, in M. Maier, J. Strömbäck and L. L. Kaid (eds.), Political Communication in European Parliamentary Elections, London: Ashgate Publishing Limited, pp. 175-194.

Statham, P., Koopmans, R., Tresch, A., and Firmstone, J. (2010) 'Political party contestation: emerging Euroskepticism or a normalization of Eurocriticism', in R. Koopmans and P. Statham (eds), The Making of a European Public Sphere. Media Discourse and Political Contention, Cambridge: Cambridge University Press, pp. 245-276.

Sunstein, C.R. (2009) Republic.com 2.0, Princeton: Princeton University Press.

Torreblanca, J.I. et al. (2013) 'The continent-wide rise of Euroscepticism’, Policy Memo, London: European Council on Foreign Relations. 
Tresch, A. (2012) 'The (partisan) role of the press in direct democratic campaigns: evidence from a Swiss vote on European integration', Swiss Political Science Review 18(3): 287-304.

Vasilopoulou, S. (2013) 'Continuity and change in the study of Euroskepticism: plus ça change?’, JCMS: Journal of Common Market Studies 51 (1): 153-168.

Wessler, H., Peters, B., Brüggemann, M., Kleinen-von-Königslöw, K., and Sifft, S. (2008) Transnationalization of Public Spheres. Houndmills: Palgrave Macmillan. 
For online supplemental material to be hosted by the publisher:

Supplemental data for this article can be accessed at [link to source - publisher will add doi at proof]

\section{Replication materials}

Supporting data and materials for this article can be accessed on the Taylor \& Francis website, doi: [publisher to add the doi at proof]. 